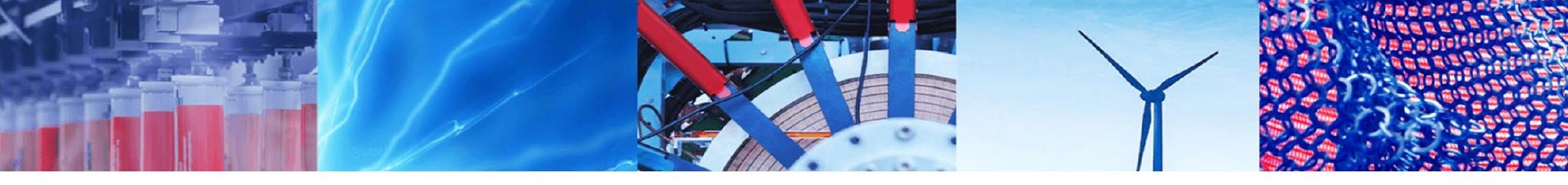

Research Article

\title{
Recovery and liquefaction of nitrogen-containing component and minerals from food processing wastes of vinegar using subcritical water
}

\author{
Kazuharu Yamato ${ }^{1,2} \cdot$ Katsuya Minami $^{1} \cdot$ Shoji Hirayama $^{3} \cdot$ Yuriko Hoshino $^{3} \cdot$ Munehiro Hoshino $^{2} \cdot$ Tetsuya Kida $^{4}$. \\ Mitsuru Sasaki $^{4,5} \cdot$ Yukihiro Matsumori $^{6}$
}

Received: 15 June 2020 / Accepted: 29 October 2020 / Published online: 25 November 2020

(c) Springer Nature Switzerland AG 2020

\begin{abstract}
In recent years, environmental problems such as production of industrial waste are getting worse in Japan. In particular, food processing residues are typically disposed of by spending a large amount of money. This paper studied the treatment of two by-products from vinegar production (rice bran and sake lees) using subcritical water and analyzing the extracted solution for functional ingredients. The results from sake lees showed that an operating temperature of $180^{\circ} \mathrm{C}$ and a reaction time of $30 \mathrm{~min}$ solubilized $85 \%$ of the nitrogen-containing component (mainly protein) from the raw material into water-soluble peptides. When rice bran was used as the raw material the solubilization rate of the nitrogen-containing components was greatly decreased at a reaction temperature of $190^{\circ} \mathrm{Cor}$ higher. It was shown that calcium in the raw material caused the formation of water-insoluble complexes with amino acids and ammonia such as $\mathrm{CaCN}_{2}$. Subcritical water treatment was shown to be a useful technique to recover useful water-soluble components from residual solid biomass.
\end{abstract}

Keywords Biomass · Green chemistry · Subcritical water extraction · Hydrolysis

\section{Introduction}

Pollution due to the environmental discharge of residual organics from food processing has become a social problem all over the world. In recent years, the concept of technical innovation which is converting conventional chemical processes to more sustainable and 'green' procedures [1], has been pursued in Japan. The depletion of energy resources can be minimized by efficient utilization and conversion of waste to energy. The 'Basic Law for Promotion of Utilization of Biomass' was introduced in Japan in 2009. It is based on the philosophy of diversifying energy supply sources, and consideration for environmental conservation, and in more specific terms, it promotes biomass utilization.

Figure 1 shows the relationship between biomass conversion technology and products providing a template for value added [2]. Biomass resources are roughly classified into resource crops and waste processes in Japan. Some examples of food recycling technology are the production of fertilizer, oils and fats from food waste.

Examples of food recycling technology include the production of fertilizer from food waste for use by farmers, and the application to fats and oils and fat products.

Mitsuru Sasaki, msasaki@kumamoto-u.ac.jp | ${ }^{1}$ Graduate School of Science and Technology, Kumamoto University, 2-39-1 Kurokami, Chuo-ku, Kumamoto 860-8555, Japan. ${ }^{2}$ Maruboshi Vinegar Co. Ltd., 2425 Tabara, Kawasaki-machi, Tagawa-gun, Fukuoka 827-0004, Japan. ${ }^{3}$ Maruboshi Vinegar Ascii, Food Technology and Biology of Technical Center, 2400 Tabara, Kawasaki-machi, Tagawa-gun, Fukuoka 827-0004, Japan. ${ }^{4}$ Faculty of Advanced Science and Technology, Kumamoto University, 2-39-1 Kurokami, Chuo-ku, Kumamoto 860-8555, Japan. ${ }^{5}$ Institute of Industrial Nanomaterials, Kumamoto University, 2-39-1 Kurokami, Chuo-ku, Kumamoto 860-8555, Japan. ${ }^{6}$ Craftman Co., 3467-9 Arao, Arao 864-0041, Japan. 


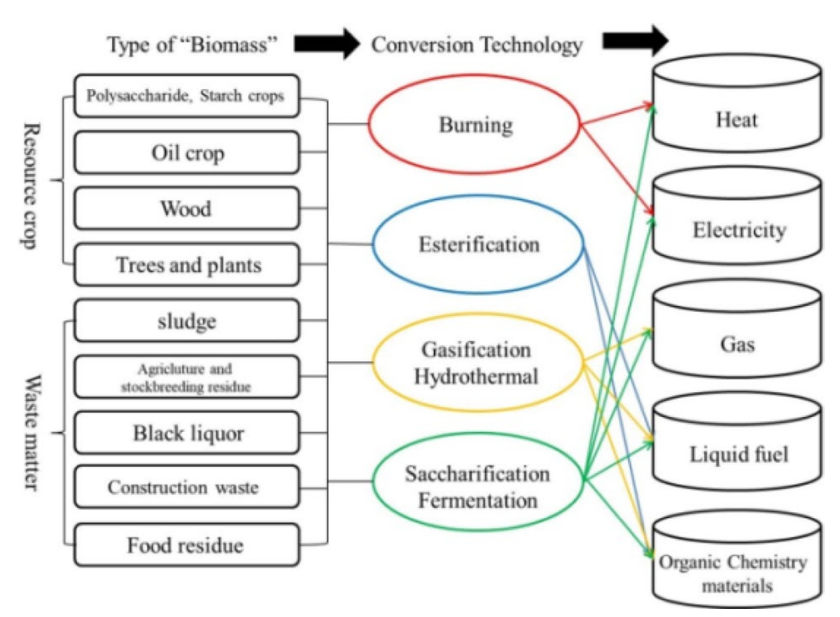

Fig. 1 Biomass conversion technologies and their products

For instance, in 2017, Japan produced 584,000 tons of rice bran and sake lees as food processing residues compared to the 78,000 tons produced in 2016 (Maruboshi vinegar production was 1 ton of rice bran, and 15 tons of sake lees per year in 2017) [3-6]. Efficient recycling technology would not only reduce the volume of solid waste generated but also reduce the costs paid by companies for waste disposal, thus increasing revenue. Hence, wide spreading of the use of this concept will have a positive effect in the economy of the country. Furthermore, vinegar industries can obtain high value-added vinegar by adding acetic acid to the subcritical water extract and brewing it again. This process is regarded as an epoch-making technology since the residues of vinegar production is not discarded. Furthermore, in the vinegar industry, by adding acetic acid to the subcritical water extract and brewing it again, there is a possibility that it can be reused as high value-added vinegar. This is an epoch-making technology because the vinegar residue is not discarded.

The term subcritical water, refers to a state of water before reaching the critical state, meaning that pressure and temperature conditions are lower than its stablished critical point. At this point, the state of matter is determined by pressure and temperature conditions. Substances have intrinsic intermolecular distances, and phase changes occur under substance-specific conditions. However, there is a point at which it does not liquefy even if it is compressed above a certain temperature; this is called the critical point.

The critical temperature of water is $374.2^{\circ} \mathrm{C}$, and its critical pressure is $22.1 \mathrm{MPa}$, water at temperature and pressure conditions beyond these conditions is called supercritical water. This state combines the diffusibility of a gas and the reactive properties of a liquid and can be described as high-density gas. In subcritical water, molecules of water with high thermal energy due to high temperature are in a

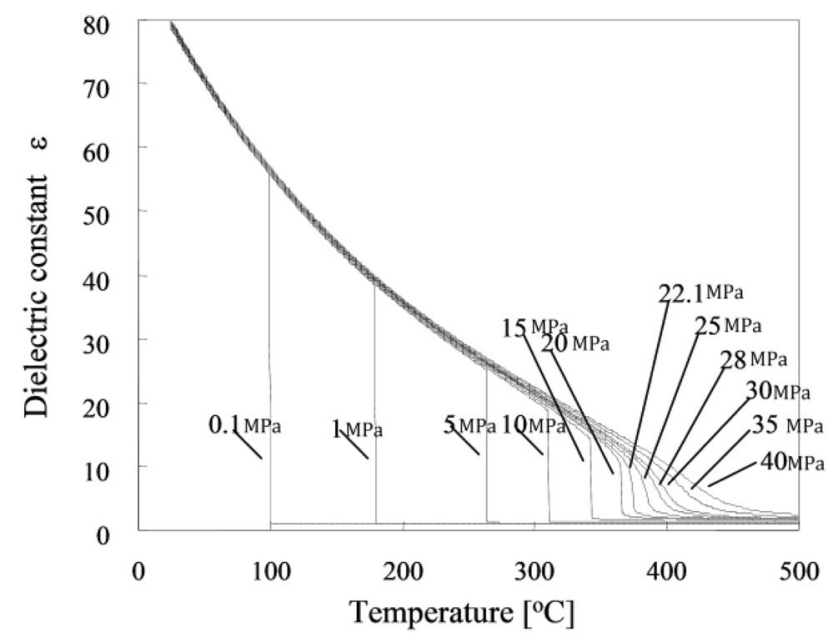

Fig. 2 The ion product of water

liquid state due to high pressure; it has both the properties of the gas that can enter any (narrow intermolecular gap) and like liquids, possesses the property to melts things. Figure 2 shows the ion product of water.

The ionic product constant (KW) of subcritical water is about 1000 times higher than in its normal state and ion dissociation of water occurs easily. In addition, the relative dielectric constant also has a high value of about 20-50, which increases its solvent capacity to the point that it is as soluble as alcohol and is easily hydrolyzed. Water molecules in this state have been reported to exhibit a catalytic function only by bias of charge [7]. Water in this state has the ability to act as an acid or an alkaline catalyst and is able to accelerate the hydrolysis reaction. Even in a high temperature region exceeding its critical temperature, the ion product can take a high value under a sufficiently highpressure condition of $40-100 \mathrm{MPa}$.

Subcritical water can catalyze various chemical reactions; for instance, it hydrolyzes the cellulose in rice straw and chaff to form low-molecular-weight, solubilized compounds used for bioethanol fermentation [8-13], and can also solubilize sewage sludge [14-21]. By utilizing this feature, it is possible to create techniques for producing useful components in an environmentally friendly manner without using conventional chemicals. (i.e. organic solvents, inorganic acids, and expensive metal catalysts.)

Application of subcritical water to the solubilization and hydrolysis of proteins and sugars in food processing residues is a greener reaction technology that has the potential to enhance the effective utilization of biomass and reduce solid waste. This study focuses on rice bran and sake; which are high-volume food processing residues and investigates its treatment with subcritical water and nitrogen-containing compounds to extraction the mineral components $(\mathrm{K}, \mathrm{Ca}, \mathrm{Mg})$ at high concentrations. 


\section{Experimental section}

\subsection{Materials}

Rice bran and sake lees provided by Maruboshi vinegar corporation (Fukuoka) were used as raw materials, as shown in Fig. 3.

Their chemical compositions are shown in Table 1. Distilled water was used as a solvent in the subcritical water treatment. Standard substances used in the quantitative analysis of amino acids are also shown in Table 1.

\subsection{Experimental apparatus and procedure}

An autoclave shown in Fig. 4 was used to treat biomass residues in water at high temperatures and high pressures.

The reactor was constructed from SS 316 steel and has an internal volume of $500 \mathrm{~mL}$. The reactor was charged with $45 \mathrm{~g}$ of raw material and $300 \mathrm{~mL}$ of distilled water, mixed with a stirrer, and then sealed. Thereafter, the temperature was raised to a predetermined setpoint $\left(160-225^{\circ} \mathrm{C}\right)$ by a band heater installed in the reactor. The heating time was 15 to $30 \mathrm{~min}$. After reaching the predetermined temperature, the contents were reacted for 15-120 min while stirring at $300 \mathrm{rpm}$. The pressure in the reactor varied from 1.3 to $2.6 \mathrm{MPa}$ depending on the vapor pressure of water and the product gas evolved during processing. After the subcritical water treatment, the band heater was removed from the reactor and a fan was used

(a) Rice bran

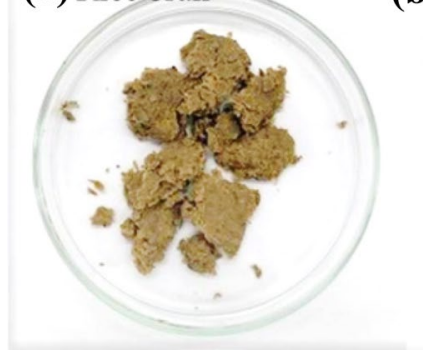

(b)

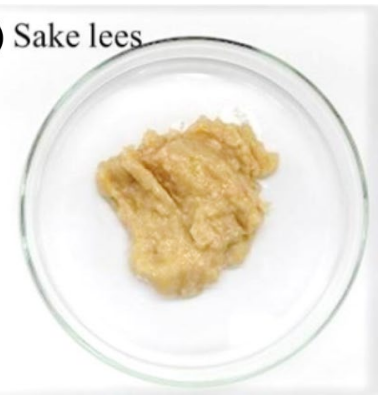

Fig. 3 Raw materials used in this study: (a) Rice bran, and (b) Sake lees

Table 1 Composition of sake lees and rice bran

\begin{tabular}{lllllrr}
\hline & $\begin{array}{l}\text { Moisture con- } \\
\text { tent [\%] }\end{array}$ & TN [ppm-N] & $\begin{array}{l}\text { Water soluble amino acid } \\
\text { amount [ppm-N] }\end{array}$ & TOC [ppm-C] & $\begin{array}{c}\text { Ammonic nitrogen } \\
\text { content [ppm-N] }\end{array}$ & $\begin{array}{l}\text { Mineral } \\
\text { amount } \\
{[\mathrm{ppm}]}\end{array}$ \\
\hline Rice bran & 9.69 & 1900 & 43.6 & 8.485 & 4.2 & 23.9 \\
Sake lees & 56.2 & 2510 & 127.1 & 8.835 & 21.3 & 96.5 \\
\hline
\end{tabular}


Table 2 Amino acids quantitatively analyzed in this study

\begin{tabular}{llll}
\hline 1. Aspartic acid & 2. Glutamic acid & 3. Serine & 4. Histidine \\
5. Glycine & 6. Threonine & 7. Arginine & 8. Alanine \\
9. Tyrosine & 10.Valine & 11. Methionine & $\begin{array}{c}\text { 12. Phenyla- } \\
\text { lanine }\end{array}$ \\
13. Isoleucine & 14. Leucine & 15. Lysine & 16. Proline
\end{tabular}

\subsubsection{Total nitrogen concentration}

Quantitative determination was made by dividing nitrogen into total nitrogen and ammonia-nitrogen, and the Kjeldahl method [22] was used for total nitrogen.

\subsubsection{Ammonia nitrogen concentration}

Analysis of ammonia-nitrogen was carried out using the Indophenol method [23].

\subsubsection{Phosphorus content}

Phosphorus content was determined using the molybdenum blue method [24].

\subsubsection{Minerals}

Three minerals: potassium, calcium and magnesium were quantitatively determined by atomic absorption spectrometry (AA-7000 by SHIMADZU).

\subsection{Definitions of formulas}

\subsubsection{Solubilization ratio of raw material}

Raw material solubilization ratio $=$ water - soluble nitrogen yield

$=\mathrm{TN}$ concentration $[\mathrm{ppm}-\mathrm{N}] /$ total amino acid concentration

treated with $\mathrm{HCl}[\mathrm{ppm}-\mathrm{N}]$

\subsubsection{Water-soluble peptide yield}

Water_Soluble Peptide Yield = Water_Soluble Nitrogen Yield

- Amino Acid Yield Ammonia Yield

\subsubsection{Amino acid yield}

Amino acid yield = Amino acid concentration [ppm $-\mathrm{N}]$

$/ \mathrm{HCl}$ Total amino acid concentration treated [ppm - N]

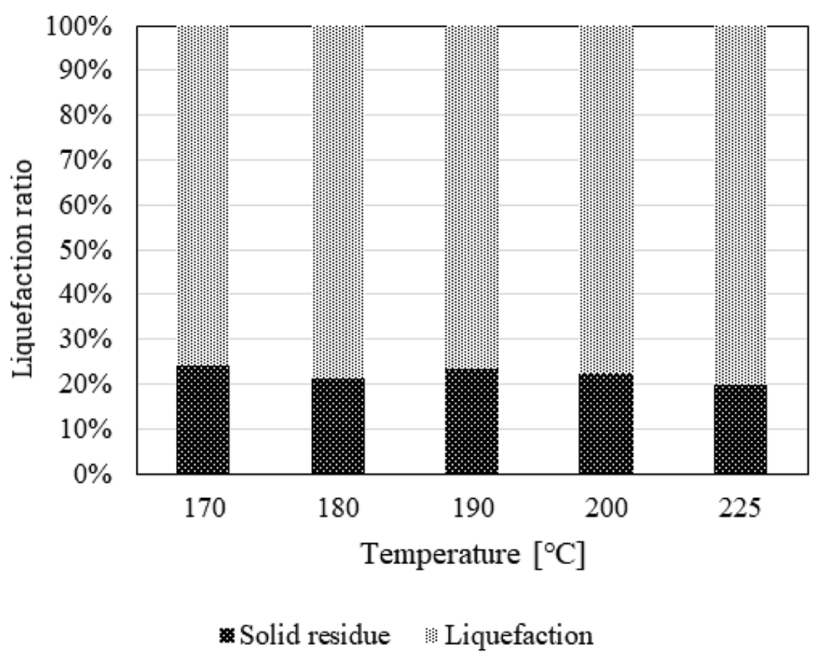

Fig. 5 Effect of temperature on the liquefaction strength-ratio of sake lees through the subcritical water treatment for $30 \mathrm{~min}$

\subsubsection{Ammonia yield}

Ammonia yield $=$ ammonia - nitrogen concentration $[\mathrm{ppm}-\mathrm{N}]$

$/ \mathrm{HCl}$ Total amino acid concentration treated [ppm - N]

\subsubsection{Total organic carbon (TOC)}

TOC $=$ Total Carbon (TC) - Inorganic Carbon (IC)

\subsubsection{Mineral amount}

Mineral amount $=\mathrm{K}$ concentration + Ca concentration

$$
+ \text { Mg concentration }
$$

\section{Results and discussion}

\subsection{Subcritical water treatment of sake lees}

\subsubsection{Effect of temperature on the liquefaction strength ratio}

Relationship between the liquefaction rate of sake lees and operating temperature on the subcritical water treatment for $30 \mathrm{~min}$ was investigated, and the results are shown in Fig. 5. The liquefaction rate was in the range of $75-80 \%$ in spite of a temperature change from 170 to $225^{\circ} \mathrm{C}$. 


\subsubsection{Effect of temperature on the recovery of organic and inorganic compounds}

We decided to consider the total concentrations of peptides as total amino acids. Figure $6 a$ shows the results of comparing the water-soluble peptides, total amino acids, and ammonia-nitrogen when the treatment time was kept constant for $30 \mathrm{~min}$ and the sake lees were treated at a treatment temperature of $170-225^{\circ} \mathrm{C}$. The data shown in Fig. 6 a suggested that the water-soluble peptides were degraded and decreased with increasing temperature, and that amino acids could be recovered more efficiently at low temperature.

It was noted that the amino acids increased again at $225^{\circ} \mathrm{C}$. Amino acids are produced by decomposition of proteins and peptides which are then decomposed into ammonia, and the yield is determined from these two factors. An increase in the amount of amino acids measured at $225^{\circ} \mathrm{C}$ is conceivably caused by the decrease of the water-soluble peptide concentration exceeded by the ammonia concentration. The concentration of total amino acids released from sake lees were higher than that of rice bran, the details will be later discussed. A possible reason for this is that sake lees are obtained downstream of the rice bran in the vinegar process, so any proteins therein were more likely to be decomposed into amino acids.

Figure $6 \mathrm{~b}$ shows the temperature and time dependence of the released phosphoric acid, phosphorus, and minerals from sake lees on subcritical water treatment. Use of subcritical water treatment under appropriate operating conditions made it possible to extract these minerals from sake lees into the aqueous phase. In addition, it was found that phosphorus present in sake lees can be recovered by appropriate temperature adjustment.

\subsubsection{Effect of treatment time on the hydrolysis of protein fraction and minerals}

Figure 7a shows the nitrogen balance in water-soluble organic compounds after treatment with subcritical water using sake lees as a raw material. Approximately $90 \%$ of protein was successfully converted into water-soluble peptide, amino acids, and ammonia after $30 \mathrm{~min}$ at $>160^{\circ} \mathrm{C}$. This additional study investigated suitable operating conditions under which water-soluble nitrogen-containing components can be obtained from sake lees. Nitrogencontaining components were classified as protein, free amino acids, uric acid, nitrate nitrogen, and ammonianitrogen. During subcritical water treatment, the peptide bond of the water-insoluble peptide in the raw material is converted into a water-soluble peptide or amino acid.

Figure $7 \mathrm{~b}$ shows the time dependence of phosphoric acid, phosphorus, and minerals of sake lees in subcritical water treatment at $180^{\circ} \mathrm{C}$. By conducting the subcritical water treatment under appropriate operating conditions, it was possible to extraction minerals from the sake lees into the aqueous phase without measurable loss. (a)

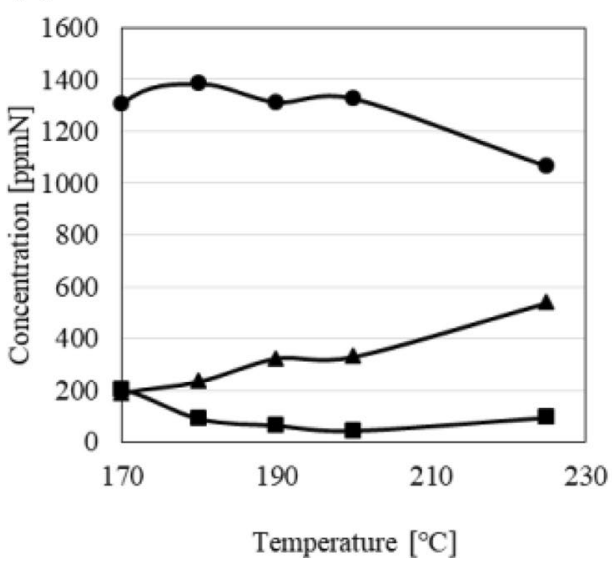

Fig. 6 Behavior of the nitrogen-containing components obtained after the subcritical water treatment of sake lees at $180{ }^{\circ} \mathrm{C}$ for 30 min: (a) water-soluble peptides, amino acids and ammonia (Symbols: (black circle) water-soluble peptides, (black square) total amino acids, and (black up-pointing triangle) ammonia); (b) phos- (b)

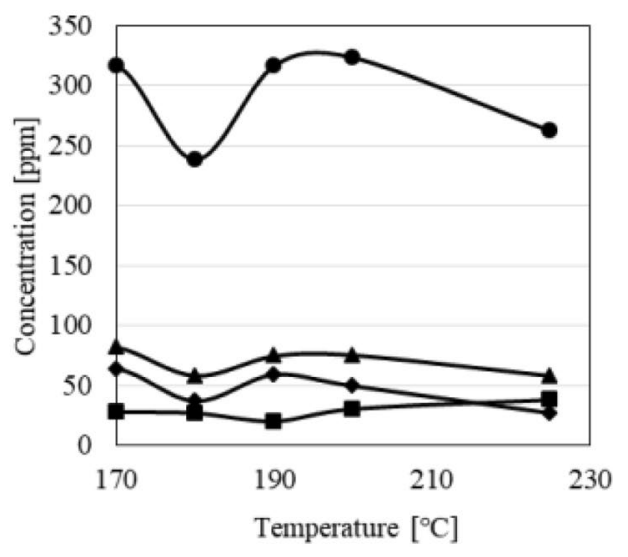

phorus (all phosphorus derived from phosphoric acid) and minerals (Symbols: (black circle) phosphorus, (black up-pointing triangle) potassium, (black square) calcium, and (black diamond suit) magnesium) 
Fig. 7 Time course of the nitrogen-containing components obtained after the subcritical water treatment of sake lees at $180^{\circ} \mathrm{C}$ : (A) organic compounds and ammonia ((a) water-insoluble protein, (b) water-soluble peptides, (c) total amino acids, and (d) ammonia); (B) phosphorus and minerals (Symbols: (black circle) phosphorus, (black up-pointing triangle) potassium, (black square) calcium, and (black diamond suit) magnesium) (a)

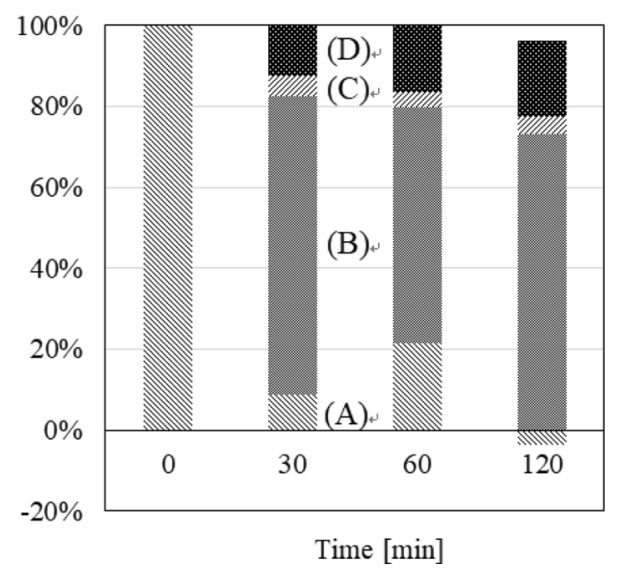

(b)

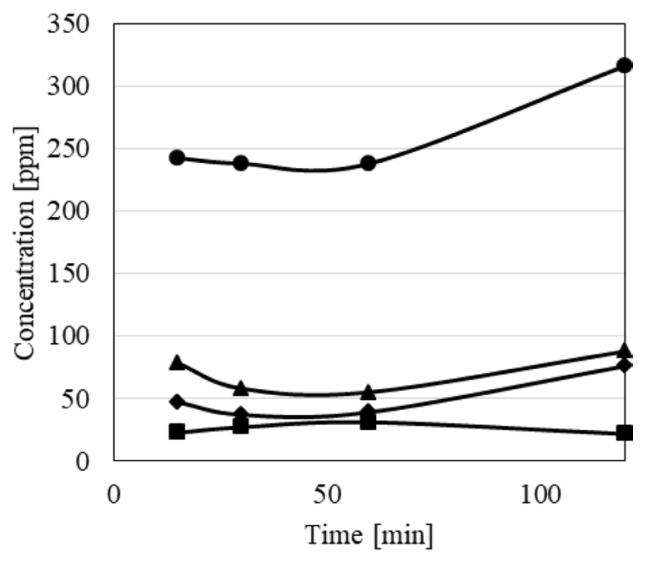

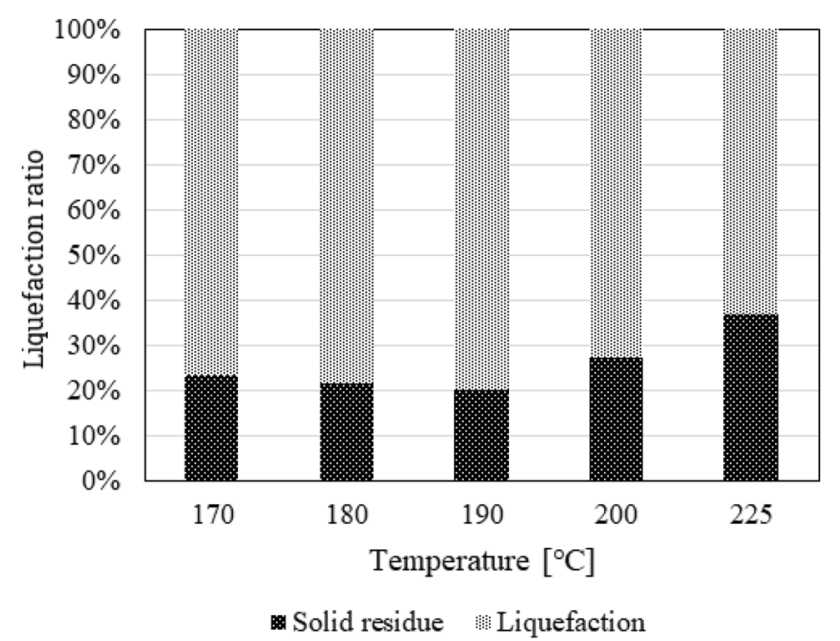

Fig. 8 Effect of temperature on the liquefaction strength ratio of rice bran through subcritical water treatment for $30 \mathrm{~min}$

\subsection{Subcritical water treatment of rice bran}

\subsubsection{Effect of temperature on the liquefaction strength ratio}

The relationship between the liquefaction rate of rice bran and operating temperature on the subcritical water treatment for 30 min was investigated. Figure 8 shows that the liquefaction rate in the range of $170-190^{\circ} \mathrm{C}$ was almost the same level (about $80 \%$ ). The rate was reduced with increasing operating temperature most probably due to the combination of hydrolysis products that were formed during the subcritical water treatment.

\subsubsection{Effect of temperature on the recovery of organic and inorganic compounds}

Figure 9a compares the water-soluble peptides, total amino acids and ammonia-nitrogen released from rice bran after $30 \mathrm{~min}$ at a treatment temperature of $170-225^{\circ} \mathrm{C}$. Water-soluble peptides were degraded and
Fig. 9 Temperature dependence on the elution profile of functional ingredients after $30 \mathrm{~min}$ of exposure to subcritical water: (a) watersoluble peptides, amino acids and ammonia (Symbols: (black circle) water-soluble peptides, (black square) total amino acids, and (black up-pointing triangle) ammonia); (b) phosphorus and minerals (Symbols: (black circle) phosphorus, (black up-pointing triangle) potassium, (black square) calcium, and (black diamond suit) magnesium) (a)

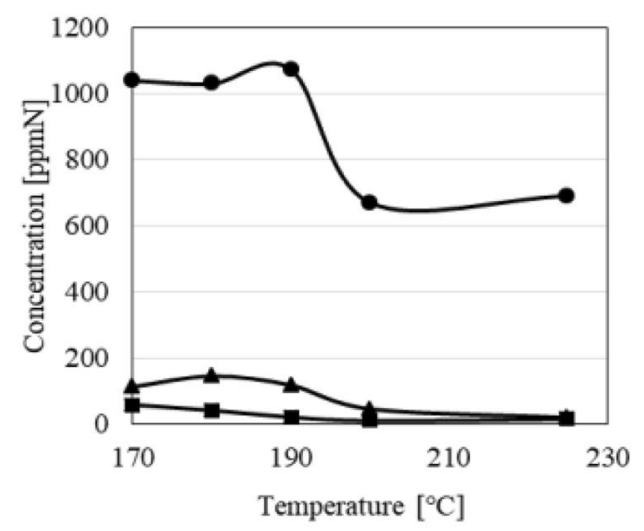

(b)

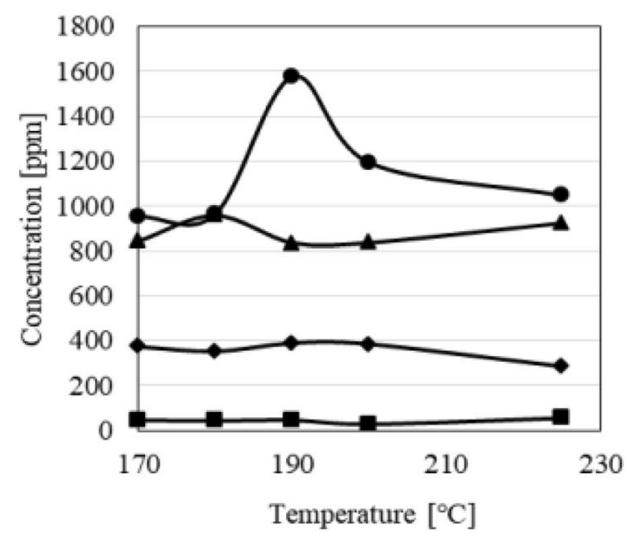


decreased in concentration with increasing temperature which suggests that the amino acids could be more effectively recovered at lower temperatures.

Ammonia increased due to decomposition of water-soluble peptides and amino acids in the case of sake lees as shown in Fig. 6a, but in the case of rice bran, which is rich in minerals, the minerals and ammonia reacted to become solids, such as $\mathrm{Mg}_{3} \mathrm{~N}_{2}$ and $\mathrm{CaCN}_{2}$. In fact, when treated at $225^{\circ} \mathrm{C}$, many solid residues remained. Total amino acid concentration was found to be lower in rice bran compared to sake lees. We consider the reason for this to be that the rice bran is generated upstream from sake lees in the manufacturing process of vinegar, so the protein contained in this residue was not as easily decomposed into amino acids.

Figure $9 \mathrm{~b}$ shows the temperature and time dependence of the release of phosphoric acid, phosphorus, and minerals from rice bran by subcritical water treatment. Comparison between Figs. $6 \mathrm{~b}$ and $9 \mathrm{~b}$ indicate that phosphorous and minerals were more abundant in rice bran than in sake lees. It is considered that these large amounts of phosphorus and minerals may have reacted with ammonia to form a solid as discussed in Sect. 3.2.1.

\subsubsection{Effect of treatment time on the hydrolysis of protein and mineral fractions}

Rice bran was treated with subcritical water to obtain a liquefaction rate of about $88 \%$ at $30 \mathrm{~min}$ and $60 \mathrm{~min}$ (see Fig. 10a). Treatment for 120 min resulted in carbonization and high recovery of solid residue. It is suggested that the low liquefaction of rice bran is due to its lower water content, which promoted carbonization instead. In addition, water-soluble peptides, total amino acids, and ammonia decreased with treatment time. Water-soluble peptides and amino acids were suggested to be overdegraded due to an increase in subcritical water treatment time. The ammonia in the rice bran behaved differently than that in sake lees. It is suggested that higher mineral content in the rice bran reacted with ammonia to form solids such as magnesium nitride $\mathrm{Mg}_{3} \mathrm{~N}_{2}$ and lime nitrogen $\mathrm{CaCN}_{2}$. The concentrations of potassium and calcium did not change with increasing treatment time while the concentration of phosphorus gradually increased with time up to $1 \mathrm{~h}$ and that of magnesium was decreased within $0.5 \mathrm{~h}$ (see Fig. 10b).

\subsection{Effect of feedstock ratio on component composition}

As shown previously, the liquefied aqueous solution from sake lees contained a high concentration of amino acids and the one from rice bran had a large amount of minerals. In order to produce a high-quality liquefaction product, we investigated subcritical water treatment $\left(180^{\circ} \mathrm{C}\right.$, $30 \mathrm{~min}$ ) using three mixing ratios of rice bran (R) to sake lees $(S)$ in the feedstock $(R / S=3 / 1,1 / 1$ and $1 / 3)$. The total amino acid concentration in the mixed aqueous solution increased proportionally with the R/S ratio, as shown in Fig. $11 \mathrm{a}$ and $\mathrm{b}$, and the concentrations of minerals showed a similar trend. These results indicate that there is no interaction between organic and inorganic compounds produced despite the starting materials being mixed and treated in subcritical water. This finding clearly indicates that a desired composition of amino acids and minerals can be prepared by the appropriate mixing of these two agricultural feedstocks.
Fig. 10 Time course of the elution of nitrogen-containing components obtained from the subcritical water treatment of rice bran at $180^{\circ} \mathrm{C}$ : (A) organic compounds and ammonia ((a) water-insoluble protein, (b) water-soluble peptides, (c) total amino acids, and (d) ammonia); (B) phosphorus and minerals (Symbols: (black circle) phosphorus, (black uppointing triangle) potassium, (black square) calcium, and (black diamond suit) magnesium) (a)

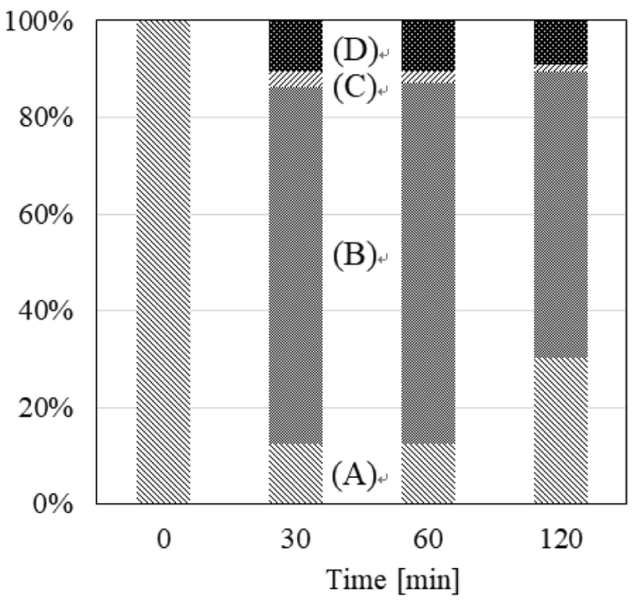

(b)

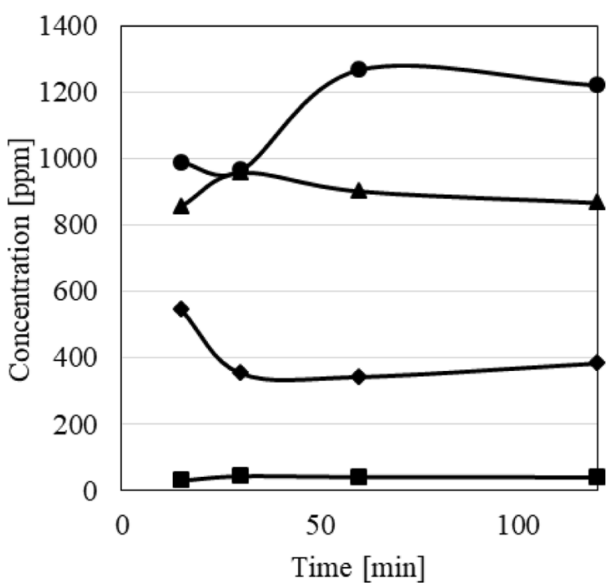


Fig. 11 Effect of the material ratio of Rice bran to sake lees $(\mathrm{R} / \mathrm{S})$ on the concentration of total amino acids (a) and the concentration of phosphorus and minerals (b). (Symbols: (black circle) phosphorus, (black up-pointing triangle) potassium, (black square) calcium, and (black diamond suit) magnesium) (a)

(b)

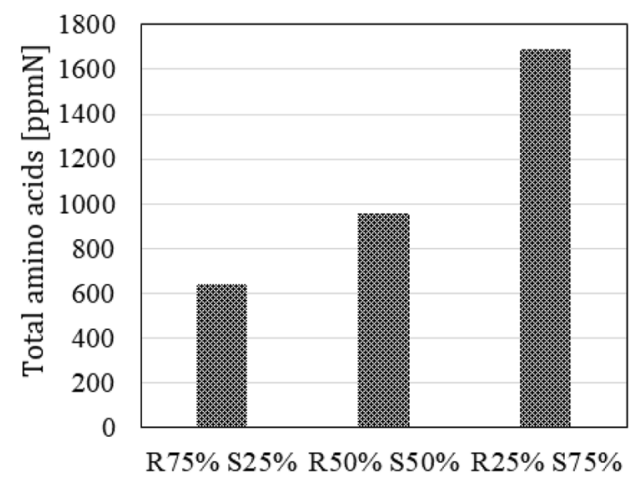

$\mathrm{R} / \mathrm{S}$ ratio

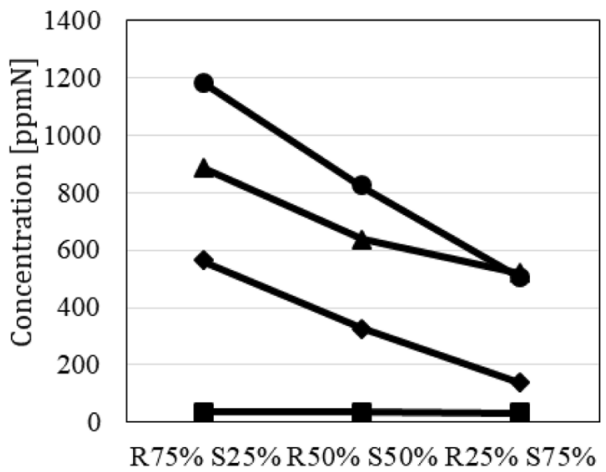

$\mathrm{R} / \mathrm{S}$ ratio

\section{Conclusions}

In this study, subcritical water treatment was applied to two biomass-based food processing residues: rice bran and sake lees. Analysis was conducted on the inclusion and recovery of functional ingredients. It was shown that phosphorus and minerals can be recovered from rice bran, and amino acids and nitrogen can be recovered from sake lees. Simultaneous recovery of valuable components can be achieved by subjecting a mixed feedstock to subcritical water treatment using distilled water as a solvent.

Future studies will investigate the addition of acetic acid bacteria to the subcritical water-treated solution in order to develop a novel vinegar containing higher concentrations of functional ingredients than the vinegar produced by traditional brewing.

Acknowledgments This research was carried out with the support of The Institute of Pulsed Power Science at Kumamoto University.

Funding This study was not funded.

\section{Compliance with ethical standards}

Conflict of interest The authors declare that they have no conflict of interest.

\section{References}

1. Shah AA, Toor SS, Seeehar TH, Nielsen RA, Nielsen AH, Pedersen TH, Rosendahl LA (2020) Bio-crude production through aqueous phase recycling of hydrothermal liquefaction of sewage sludge. Energies 13:493

2. Matayeva A, Bianchi D, Chiaberge S, Cavani F, Basile F (2019) Elucidation of reaction pathways of nitrogenous species by hydrothermal liquefaction process of model compounds. Fuel 240:169-178

\section{SN Applied Sciences}

3. Ovsyannikova E, Kruse A, Becker GC (2020) Feedstock-dependent phosphate recovery in a pilot-scale hydrothermal liquefaction bio-crude production. Energies 13:379

4. Abaide ER, Tres MV, Zabot GL, Mazutti MA (2019) Reasons for processing of rice coproducts: reality and expectations. Biomass Bioenergy 120:240-256

5. Abaide ER, Mortari SR, Ugalde G, Valerio A, Amorin SM, Luccio MD, Moreira R d FPM, Kuhn RC, Priamo WL, Tres MV, Zabot GL, Mazutti MA (2019) Subcritical water hydrolysis of rice straw in a semi-continuous mode. J Clean Prod 209:386-397

6. Garrote G, Falque E, Domínguez H, Parajó JC (2007) Autohydrolysis of agricultural residues: study of reaction byproducts. Bioresour Technol 98:1951-1957

7. Hosokawa I, Oshima F (1973) An improved method of phosphorus analysis in sea water. Water Res 7:283

8. Nojiro K, Kozaki M, Yoshii H, Koizumi T (2001) Revision Zymurgy. Kodansha, pp 74-75

9. Qian L, Wang S, Savage PE (2017) Hydrothermal liquefaction of sewage sludge under isothermal and fast conditions. Bioresour Technol 232:27-34

10. Ministry of Agriculture, Forestry and Fisheries: The crops statistics in the (2017) http://www.maff.go.jp/j/tokei/kouhyou/sakum otu/sakkyou_kome/index.html

11. Ministry of Agriculture, Forestry and Fisheries: The room for consumer. http://www.maff.go.jp/j/wpaper/w_maff/h21_h/trend/ part1/chap1/c1_03.html

12. Ministry of Economy, Tread and Industry Agency for Natural Resources and Energy: Annual Report on Energy (2007) http:// warp.da.ndl.go.jp/info:ndljp/pid/11194359/www.enecho.meti. go.jp/about/whitepaper/2007pdf/

13. National Tax Administration Agency, The liquor year refined Sake production situation in the 2016. https://www.nta.go.jp/taxes/ Sake/shiori-gaikyo/seizojokyo/2014/01.htm\#a09

14. Pharmaceutical Society of Japan, Methods: Methods of Analysis in Health Science in 2000 [publisher?]

15. Anastas PT, Warner JC (2007) Green chemistry. Maruzen

16. Hao S, Ren S, Zhou N, Chen H, Usman M, He C, Shi Q, Luo G, Zhang S (2020) Molecular composition of hydrothermal liquefaction wastewater from sewage sludge and its transformation during anaerobic digestion. J Hazard Mater 383:1-11

17. Rivas S, Conde E, Moure A, Domínguez H, Parajó JC (2013) Characterization, refining and antioxidant activity of saccharides derived from hemicelluloses of wood and rice husks. Food Chem 141:495-502

18. Chiranjeevi T, Mattam AJ, Vishwakarma KK, Uma A, Peddy VCR, Gandham S, Velankar HR (2018) Assisted single-step acid 
pretreatment process for enhanced delignification of rice straw for bioethanol production. ACS Sustain Chem Eng 6:8762-8774

19. Doctor N, Kayan B, Parker G, Vang K, Yang Y (2020) Stability and extraction of vanillin and coumarin under subcritical water conditions. Molecules 25:1-9

20. Doctor N, Yang Y (2018) Molecules separation and analysis of aspirin and metformin $\mathrm{HCl}$ using green subcritical water chromatography. Molecule 23(9):2258

21. Doctor N, Yang Y (2018) Destruction of polychlorinated biphenyls under subcritical water conditions in the presence of hydrogen peroxide or sodium hydroxide. Int J Chem Eng Appl 9(4):119-122

22. Marshall W, Franck E (1981) lon product of water substance, 0-1000 ${ }^{\circ} \mathrm{C}, 1-10000$ bars - new international formulation and its Background. J Phys Chem 10:295-304
23. Arakawa Y, Akagi I, Yamamoto K (2003) Determination of ammonium nitrogen in $\mathrm{KCl}$ extracts of cropland soils by using 2-hydroxybiphenyl sodium salt. J Soc Soil Sci Plant Nutr 74-75:657-659

24. Ran Y, Wang YZ, Liao Q, Zhu X, Chen R, Lee DJ, Wang YM (2012) Effects of operation conditions on enzymatic hydrolysis of highsolid rice straw. Int J Hydrog Energy 37:13660-13666

Publisher's Note: Springer Nature remains neutral with regard to jurisdictional claims in published maps and institutional affiliations. 